\title{
Prediction of the uniaxial compressive strength and Brazilian tensile strength of weak conglomerate
}

\author{
Behnaz Minaeian ${ }^{1}$ and Kaveh Ahangari ${ }^{2^{*}}$ (])
}

\author{
*Correspondence: \\ kaveh.ahangari@gmail.com \\ ${ }^{2}$ Department of Mining \\ Engineering, Science \\ and Research Branch, Islamic \\ Azad University/University \\ Square, End of North Sattari \\ Highway, Po Box 14515/775 \\ \& 14155/4933, Postal Code: \\ 1477893855 Tehran, Iran \\ Full list of author information \\ is available at the end of the \\ article
}

\begin{abstract}
Uniaxial compressive strength and tensile strength considered as important parameters in characterization of rock material in rock engineering. The necessary core samples cannot always be obtained from weak and block-in-matrix conglomeratic rock. For this reason, the predictive models can employed for the indirect estimation of mechanical parameters. The study investigated correlations uniaxial compressive strength and tensile strength with point load index. Numerous specimens of weak conglomerate were collected from different sites of dams in Iran. Predictive models include regression techniques and artificial neural network. To control performance of prediction capacity of equation, root mean square error and correlation coefficients were calculated. The correlation coefficients indices were calculated as 0.96 for the uniaxial compressive strength obtained from the regression model and 0.94 obtained from artificial neural network model; 0.605 for the tensile strength obtained from the regression model and 0.638 obtained from artificial neural network model.
\end{abstract}

Keywords: ANN model, Conglomerate, Point load index, Regression model, Tensile strength, Uniaxial compressive strength

\section{Introduction}

The point load test has often been reported as an indirect measure of the compressive or tensile strength of rock [1-4]. It is commonly used in practice due to the ease of testing, simplicity of specimen preparation and possible field application. ISRM [5] suggested that the ratio between uniaxial compressive strength (UCS) and point load index $\left(\mathrm{I}_{\mathrm{s}(50)}\right)$ varies between 20 and 25, although researchers have found various ratio which is depend on rock types.

There are various studies in the literature proposing relationship between $\mathrm{I}_{\mathrm{s}(50)}$ and UCS on different rock types but not on conglomerates individually: Oztruk and Altinpinar [6], Ferentinou and Fakir [7], Basu et al. [8], Akram and Bakar [9], Quane and Russel [10], Kahraman [11], Fener et al. [12], Basu and Aydin [13], Agustawijaia [14], Cobanoglu and Celik [15], Sabatakakis et al. [16], Kahraman and Gunaydin [17]. Table 1 lists some of the equations correlating the UCS to $\mathrm{I}_{\mathrm{s}(50)}$. As shown in Table 1, the suggested ratios between UCS and $I_{s}$ indicate a very large range. While some equations conform to $\mathrm{y}=\mathrm{ax}$ form, the others conform to $\mathrm{y}=\mathrm{ax}+\mathrm{b}$ form. Also, Grasso et al. [18] and 
Table 1 Equations correlating the UCS to the point load index

\begin{tabular}{|c|c|c|}
\hline Reference & $R^{2}$ & Equation \\
\hline D'Andrea et al. [1] & - & $\mathrm{UCS}=15.3 \mathrm{I}_{\mathrm{s}(50)}+16.3$ \\
\hline Broch and Franklin [3] & - & $U C S=\left.24\right|_{S(50)}$ \\
\hline Bieniawski [4] & - & $\mathrm{UCS}=23 \mathrm{I}_{\mathrm{s}(50)}$ \\
\hline Vallejo et al. [25] & - & UCS $=\left.8.6 \ldots 16\right|_{S(50)}$ \\
\hline Chau and Wong [26] & - & $\mathrm{UCS}=12.5 \mathrm{I}_{\mathrm{s}(50)}$ \\
\hline Smith [27] & - & $\mathrm{UCS}=14.3 \mathrm{I}_{\mathrm{S}(50)}$ \\
\hline \multicolumn{3}{|l|}{ Quane and Russel [10] } \\
\hline Strong rocks & & $\mathrm{UCS}=24.4 \mathrm{I}_{\mathrm{S}(50)}$ \\
\hline Weak rocks & & $U C S=3.86\left(I_{s(50)}\right)^{2}+5.65 I_{s(50)}$ \\
\hline \multicolumn{3}{|c|}{ Tsiambaos and Sabatakakis [19] } \\
\hline Power relation & 0.82 & UCS $=7.3\left(I_{S(50)}\right)^{1.71}$ \\
\hline Linear relation & 0.75 & $U C S=23 I_{S(50)}$ \\
\hline Palchik and Hatzor [28] & - & $\mathrm{UCS}=8 \ldots 18 \mathrm{I}_{\mathrm{S}(50)}$ \\
\hline Fener et al. [12] & & $U C S=9.08 I_{s(50)}+39.32$ \\
\hline Basu and Aydin [13] & $0.97 \ldots 0.93$ & $\mathrm{UCS}=18 \ldots 21 \mathrm{I}_{\mathrm{S}(50)}$ \\
\hline Agustawijaya [14] & 0.89 & $U C S=13.4 I_{S(50)}$ \\
\hline Cobanoglu and Celik [15] & 0.76 & $U C S=8.66 I_{s(50)}+10.85$ \\
\hline \multicolumn{3}{|l|}{ Sabatakakis et al. [16] } \\
\hline $\mathrm{I}_{\mathrm{s}}<2 \mathrm{MPa}$ & 0.49 & $U C S=13 I_{S(50)}$ \\
\hline$I_{s}=2-5 \mathrm{MPa}$ & 0.36 & $U C S=\left.24\right|_{S(50)}$ \\
\hline $\mathrm{I}_{\mathrm{s}}>5 \mathrm{MPa}$ & 0.53 & $U C S=28 I_{s(50)}$ \\
\hline \multicolumn{3}{|c|}{ Kahraman and Gunaydin [17] } \\
\hline Igneous rocks & 0.68 & $\mathrm{UCS}=8.20 \mathrm{I}_{\mathrm{s}}+36.43$ \\
\hline Sedimentary rocks & 0.77 & UCS $=18: 451_{S}-13: 63$ \\
\hline Metamorphic rocks & 0.78 & $\mathrm{UCS}=29: 77 \mathrm{I}_{\mathrm{S}}-51: 49$ \\
\hline
\end{tabular}

Tsiambaos and Sabatakakis [19] derived an equation conforming to $\mathrm{y}=\mathrm{ax}^{\mathrm{b}}$ form and Quane and Russel [10] suggested an equation conforming to $\mathrm{y}=\mathrm{ax}^{2}+\mathrm{bx}$ form for weak rocks.

Although conglomeratic formations are one of the most common Neogen deposit in Iran, there is little information extant in the literature on the geomechanical characteristics of weak conglomerate rocks. In addition, estimating the geomechanical properties of conglomeratic rocks need high quality samples that can reflect either textural and cement properties. The necessary core samples cannot always be obtained from weak and block-in-matrix conglomeratic rock. For this reason, the predictive models can be employed for the indirect estimation of mechanical parameters. The main objective of this study is to evaluate the correlation between uniaxial and tensile strength with point load index. For this purpose great numbers of specimens which were collected from different formations where major engineering project such as dams, road and tunnel are under construction were tested to evaluate the correlations between the UCS test result, Brazilian test (BTS) result and the corresponding test results of $\mathrm{I}_{\mathrm{s}(50)}$. The data was analyzed statistically and also by ANN to determine the degree of correlation and the variability of result. 


\section{Experimental studies}

The conglomeratic rocks in this study are parts of thick synorogenic molasses sequence of upper Pliocene to Pleistocene age, the Bakhtiari and Hezardareh Formations. These conglomerates are composed of the argillaceous-calcareous matrix with different degree of cementation and all three different types of rocks grains (tuff, limestone, marl ...) ranging from few millimeters to about a meter. On the basis of thin-section studies carried out in the present study on the samples, conglomerates contained sub-angular quartz, chlorite and to a lesser extent plagioclase, muscovite and biotite as well as varying amounts of opaque minerals, some of which showed evidence of oxidation.

In the present study, $291 \mathrm{NX}$-sized core specimens for uniaxial compressive strength tests, Brazilian tensile strength test and point load index were prepared. The ends of the specimens were made flattened perpendicular to the axis of specimen. Their sides were smoothed and polished, and specimens were inspected to be free of cracks, fissures, veins and other flaws, which would act as selective planes of weaken and cause an undesirable change of the real properties of the rock. During the testing process premature failures through the surfaces between the grains and the cementation matrix had been seen only in 3 specimens which have been removed from data base. The UCS, PLI and BTS tests were then performed in accordance with the suggestions outlined by ISRM [20]. In addition to this for UCS ISRM [20] also suggests that the diameter of the core specimen should be related to the size of the largest grain in rock specimen by a ratio of at least 10:1. However, it was not possible to satisfy this condition due to the block-inmatrix nature of the conglomerates studied. In addition to the data from 291 samples, the data of 60 specimens for the same material from Aghchai and Khorablu dams were also utilized in this study that makes a total of 351 samples.

The results obtained and their basic test statistics are tabulated in Table 2. The UCS values of the samples ranged between 1.27 and $23 \mathrm{MPa}$, with an average value of 6.79. While the average value of PLI was 0.5 MPa values varied from 0.0085 to $3.17 \mathrm{MPa}$. BTS values changed between 0.0038 and $7.8 \mathrm{MPa}$, with an average value of $0.822 \mathrm{MPa}$.

\section{Data processing and analyses}

Simple regression models

In order to establish the predictive models among the parameters obtained in this study, simple regression analysis was performed in the first stage of the analysis. All the statistical analysis was performed using SPSS version 17.0. The relation between UCS and BTS with $\mathrm{I}_{\mathrm{s}(50)}$ were analyzed employing linear, quadratic, power, logarithmic,

Table 2 Basic statistics of the results obtained from tests

\begin{tabular}{lcll}
\hline & UCS $(\mathbf{M P a})$ & BTS $(\mathbf{M P a})$ & $\mathbf{I}_{\mathbf{s}(\mathbf{5 0})}$ (MPa) \\
\hline Std. deviation & 5.1793 & 1.2174 & 0.519 \\
Range & 21.73 & 7.80 & 3.16 \\
Minimum & 1.27 & 0.003 & 0.01 \\
Maximum & 23.00 & 7.80 & 3.17 \\
Average & 6.79 & 0.822 & 0.5 \\
$\mathrm{~N}$ & 117 & 117 & 117 \\
\hline
\end{tabular}

UCS uniaxial compressive strength (MPa), BTS tensile strength $(\mathrm{MPa}), I_{s(50)}$ point load index $(\mathrm{MPa})$ 
and exponential functions. Statistically significant and strong correlations were then selected, and regression equations were established among point load index with UCS and BTS (Table 3). Most of obtained relationships were found to be statistically significant according to the Student's $t$ test at 95\% level of confidence. As can see there is a stronger relation between UCS and $\mathrm{I}_{\mathrm{s}(50)}$. Figures 1 and 2 shows the plot of the UCS and BTS versus point load index. It should be noted that the fitting quadratic line shown in Fig. 1 is physically wrong for high values of PLI.

Table 3 Predictive models for assessing the UCS and BTS

\begin{tabular}{|c|c|c|c|c|}
\hline Equation no. & $\begin{array}{l}\text { Equation } \\
\text { type }\end{array}$ & Predictive models & $\mathrm{R}^{2}$ & Sig level \\
\hline 1 & Linear & $U C S=11.473 I_{s(50)}$ & 0.936 & 0.000 \\
\hline 2 & Logarithmic & $U C S=-1.281 \ln I_{S(50)}$ & 0.05 & 0.02 \\
\hline 3 & Quadratic & $U C S=16 I_{s(50)}-\left.2.87\right|_{s(50)} ^{2}$ & 0.986 & 0.000 \\
\hline 4 & Power & UCS $=I_{S(50)}^{0.476}$ & 0.18 & 0.000 \\
\hline 5 & Exponential & UCS $=e^{2.227} I_{S(50)}$ & 0.79 & 0.000 \\
\hline 6 & Linear & $\mathrm{BTS}=1.727 \mathrm{I}_{\mathrm{S}(50)}$ & 0.74 & 0.000 \\
\hline 7 & Logarithmic & $\mathrm{BTS}=-\left.0.067 \ln \right|_{s(50)}$ & 0.005 & 0.08 \\
\hline 8 & Quadratic & $\mathrm{BTS}=1.598 \mathrm{I}_{\mathrm{s}(50)}+0.8 \mathrm{I}_{\mathrm{s}(50)}^{2}$ & 0.74 & 0.000 \\
\hline 9 & Power & $\mathrm{BTS}=\left.\right|_{\mathrm{S}(50)} ^{0.826}$ & 0.78 & 0.000 \\
\hline 10 & Exponential & $\mathrm{BTS}=\mathrm{e}^{0.781} \mathrm{I}_{\mathrm{s}(50)}$ & 0.4 & 0.05 \\
\hline
\end{tabular}

$R^{2}$ correlation coefficients

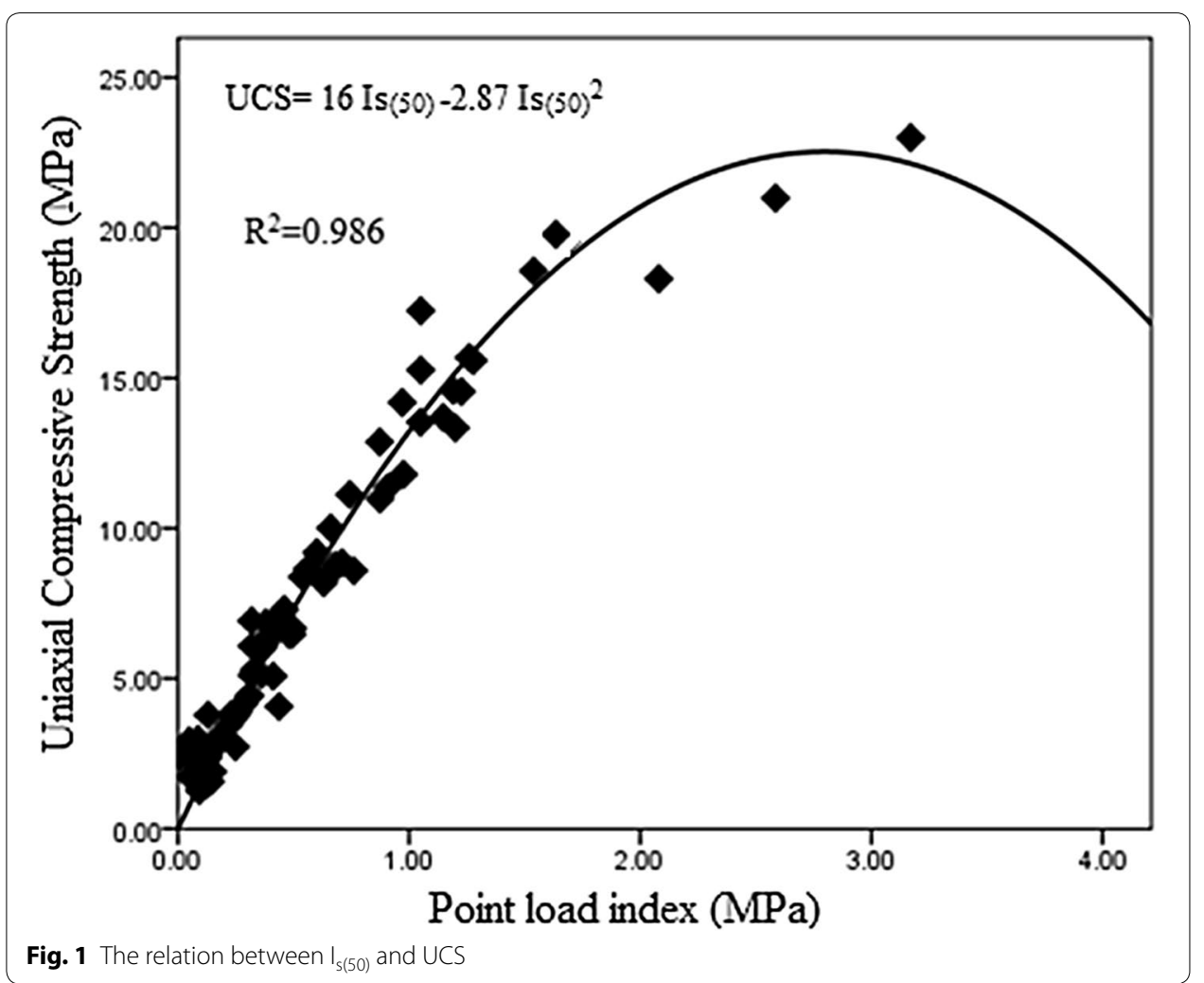




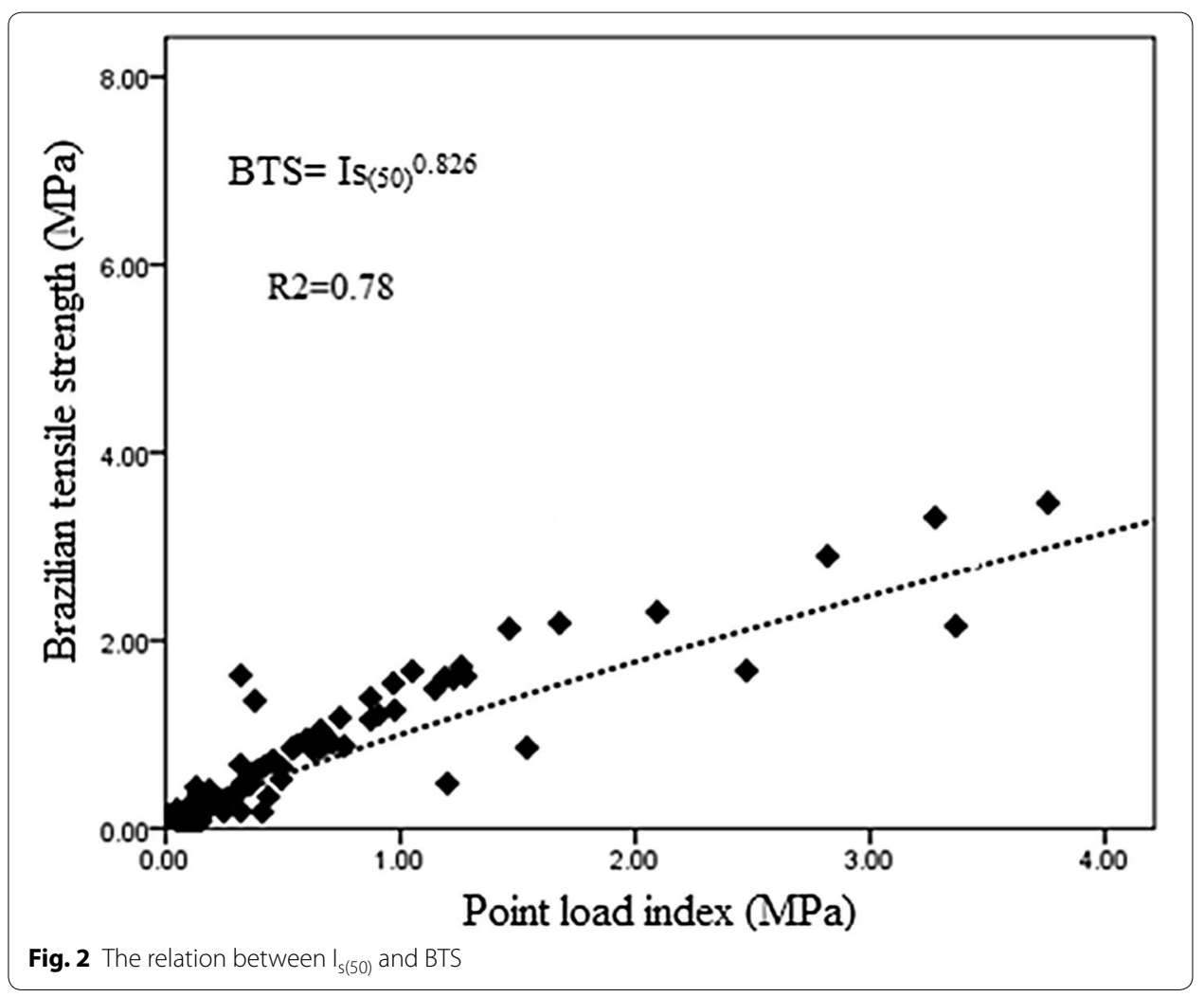

The coefficient of correlation between the measured and predictive values is a good indicator to check the prediction performance of the model. Figures 3 and 4 shows the relationships between measured and predicted obtained from the models for UCS and BTS, with good correlation coefficient $\left(\mathrm{R}^{2}\right)$. In this study, the value account for (VAF) and root mean square error (RMSE) indices were also calculated to control the performance of the prediction capacity of predictive models developed in the study, as employed by Cobanglu and Celik [15] and Yilmaz and Yuksek [21].

$$
\begin{aligned}
& \mathrm{VAF}=\left[1-\frac{\operatorname{var}(y-y)}{\operatorname{var}(y)}\right] \\
& \mathrm{RMSE}=\sqrt{\frac{1}{N} \sum_{i=1}^{N}\left(y-y^{\prime}\right)^{2}}
\end{aligned}
$$

where $y$ and y' are the measured and predicted values. The calculated indices are given in Table 4. If the VAF is 100 and RMSE is 0 , then the model will be excellent. The obtained values of VAF and RMSE, given in Table 4, indicated high prediction performances.

\section{Artificial neural networks (ANN) models}

Neural networks may be used as a direct substitute for auto correlation, multivariable regression, linear regression, trigonometric, and other statistical analysis and techniques [22]. Neural networks, with their remarkable ability to derive a general solution from complicated or imprecise data, can be used to extract patterns and detect trends that are 


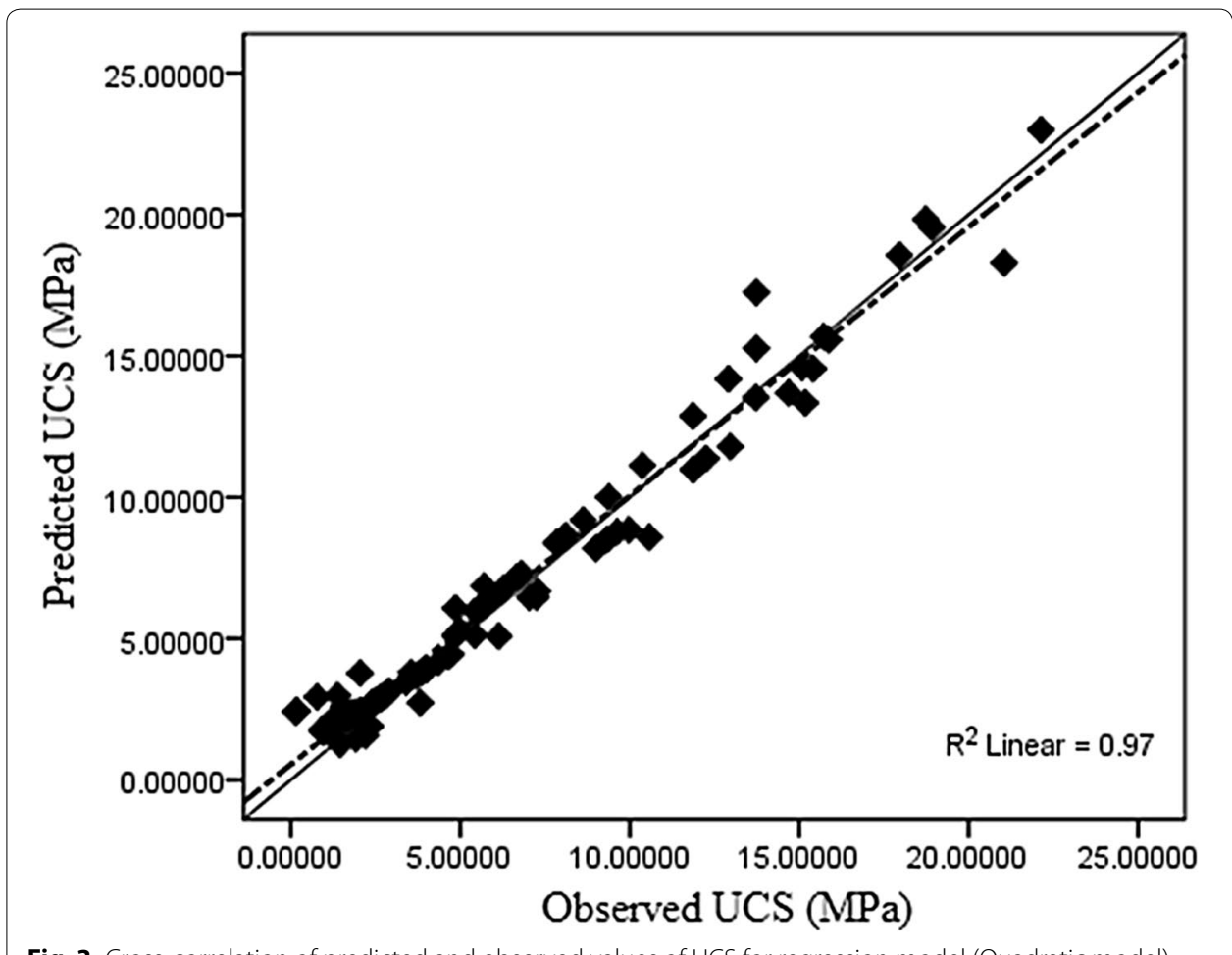

Fig. 3 Cross-correlation of predicted and observed values of UCS for regression model (Quadratic model)

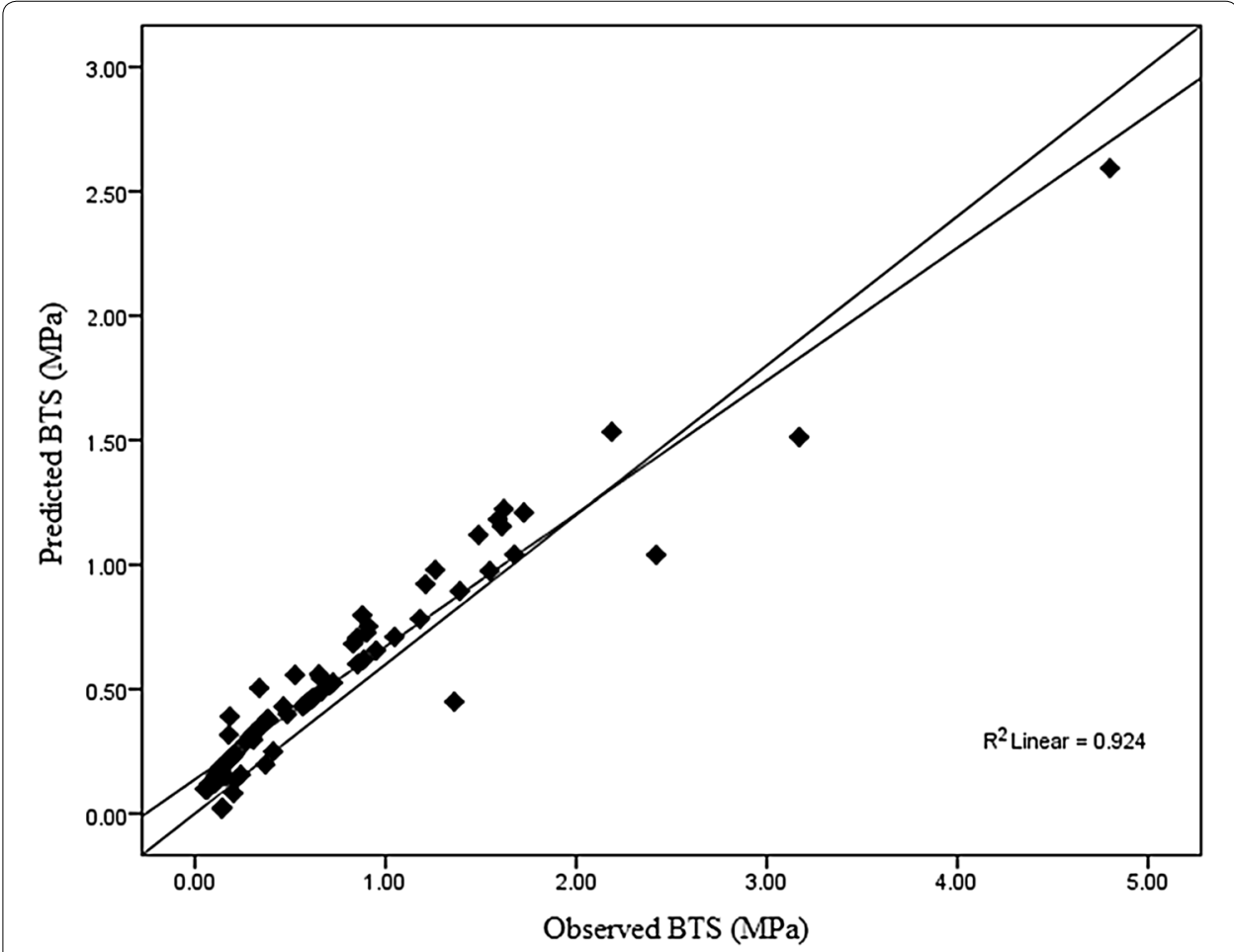

Fig. 4 Cross-correlation of predicted and observed values of BTS for regression model (Power model) 
Table 4 Performance indices (RMSE, VAF) for regression model

\begin{tabular}{lll}
\hline Predicted parameter & VAF\% & RMSE \\
\hline UCS (Quadratic model) & 96.37 & 1 \\
BTS (Power model) & 83.12 & 1.5
\end{tabular}

RMSE root mean square error, VAF\% value account for

too complex to be noticed by either humans or other computer techniques. A trained neural network can be thought of as an "expert" in the category of information it has been given to analyze. This expert can then be used to provide projections given new situations of interest and answer "what if" questions. When a data stream is analyzed using a neural network, it is possible to detect important predictive patterns that are not previously apparent to a non-expert. Thus, the neural network can act as an expert. The particular network can be defined by three fundamental components: transfer function, network architecture, and learning law [23]. It is essential to define these components, to solve the problem satisfactorily.

All data were first normalized and divided into two datasets such as: training (of all data), test (of all data). In this study Neural work profession $\prod$ software was used in neural network analyses having a three-layer feed-forward back propagation network that consists of an input layer (1 neurons), three hidden layer ( 9 neurons), and one output layer. The hidden layer has norm tangent hyperbolic transfer function neurons. Crosscorrelation between predicted and observed values which shows in Figs. 5 and 6 indicated that the ANN model constructed is highly acceptable for prediction of UCS and BTS. RMSE, VAF and $\mathrm{R}^{2}$ values are tabulated in Table 5.

\section{Results and discussion}

In this paper, use of simple regression and ANN models, for the prediction of UCS and BTS of conglomerate was described and compared.

According to the results of simple regression analyses, there are statistically meaningful relationships between UCS and BTS with point load index. Although, the most studies have suggested a linear relationship between parameters, obtained result indicate there is a quadratic relationship between UCS and $\mathrm{I}_{\mathrm{s}(50)}$ Eq. 3 and a power relationship between BTS and $\mathrm{I}_{\mathrm{s}(50)}$ Eq. 4 .

$$
\mathrm{UCS}=16 \mathrm{I}_{\mathrm{s}(50)}-2.87 \mathrm{I}_{\mathrm{S}(50)}^{2}
$$

$$
\mathrm{BTS}=\mathrm{Is}(50)^{0.826}
$$

In order to predict the UCS and BTS, ANN models having one inputs and one output was applied successfully. The results of the models for prediction of the UCS and BTS showed that the equations obtained from the regression models have high prediction performances and exhibited the more reliable predictions than the ANN model although it had been mentioned ANN models have higher prediction capacity [24], in addition UCS shows a higher correlation with $\mathrm{I}_{\mathrm{s}(50)}$ than BTS. 


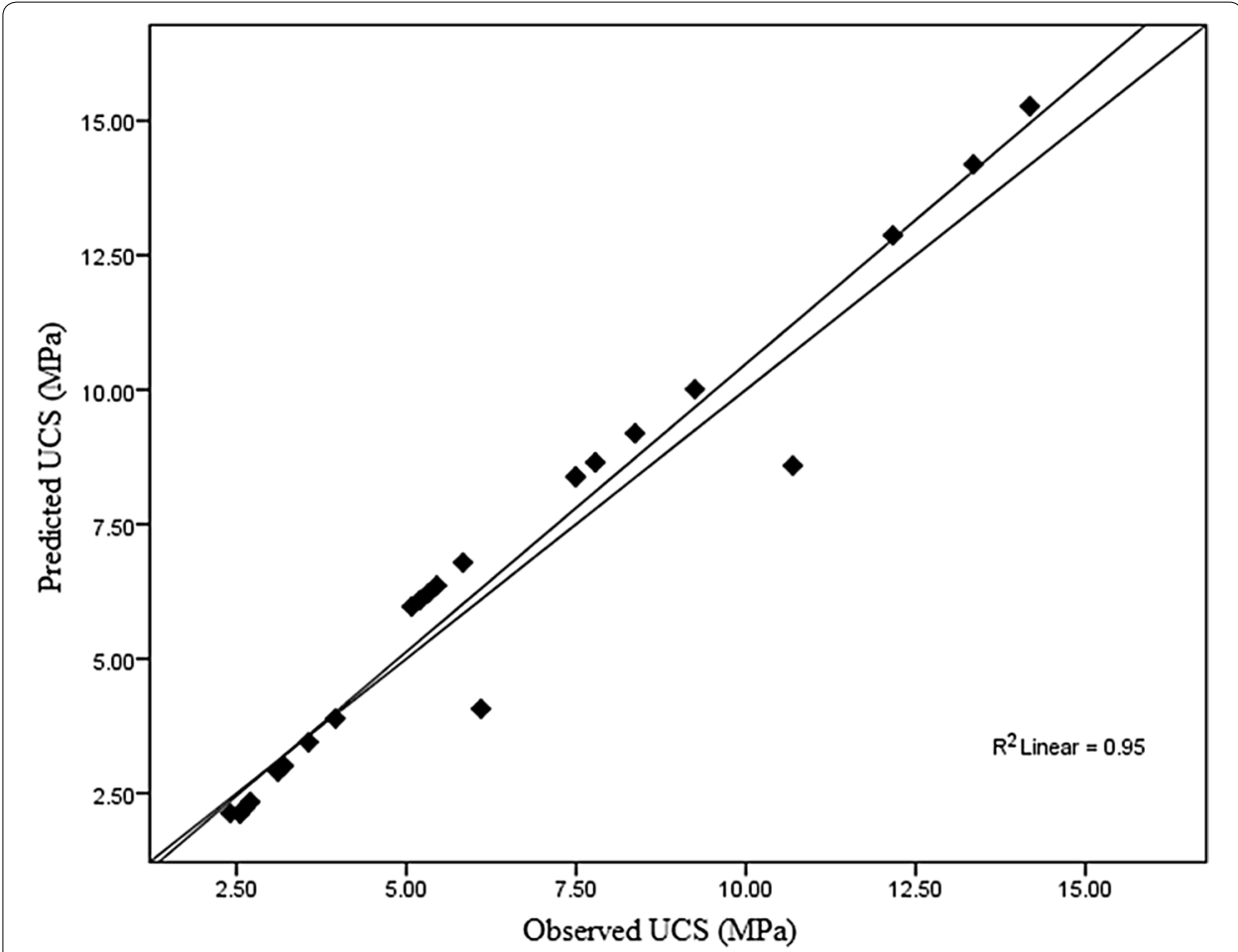

Fig. 5 Cross-correlation of predicted and observed values of UCS for ANN model

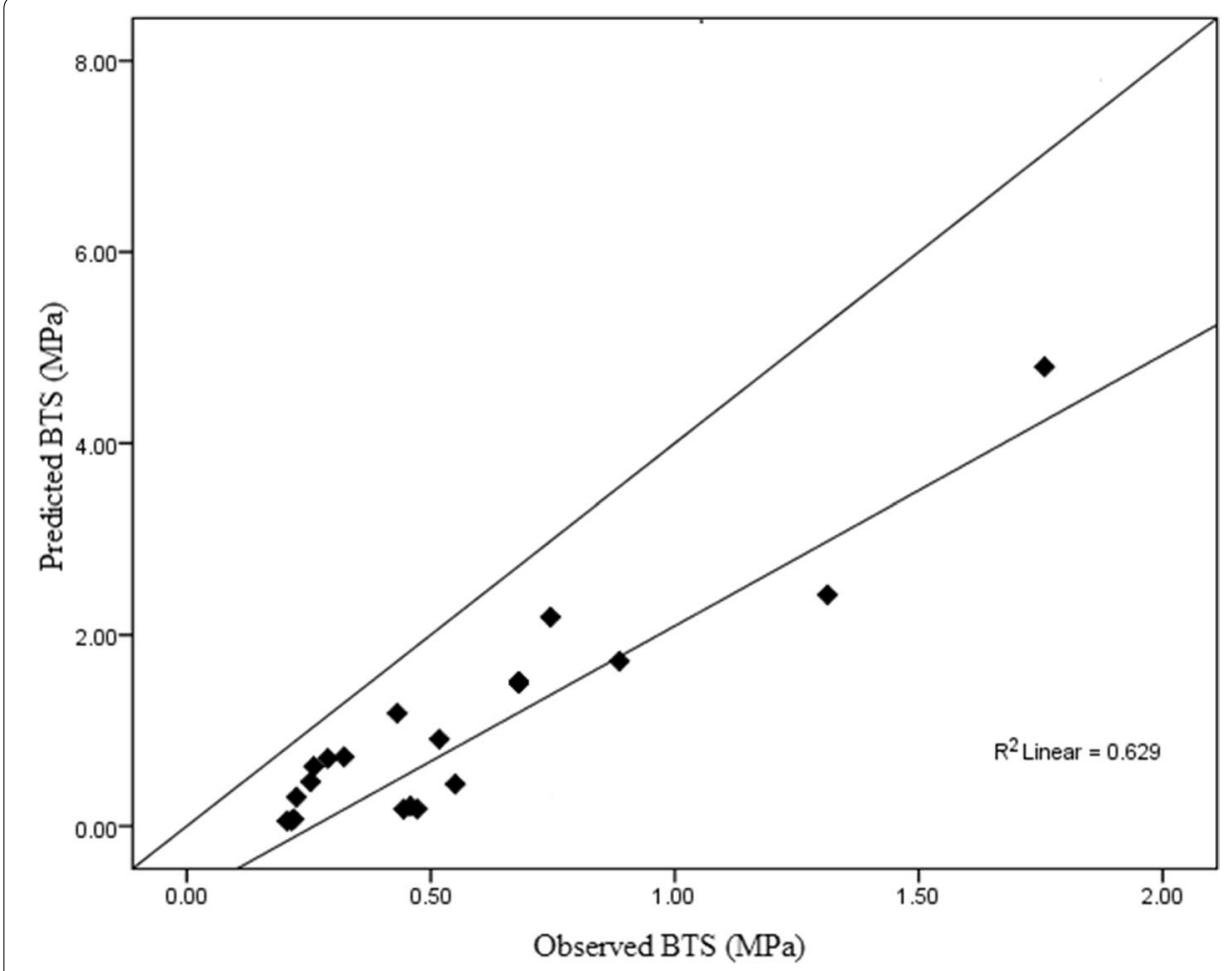

Fig. 6 Cross-correlation of predicted and observed values of BTS for ANN model 
Table 5 Performance indices (RMSE, VAF and $\mathbf{R}^{2}$ ) for ANN model

\begin{tabular}{llll}
\hline Predicted parameter & VAF\% & RMSE & $\mathbf{R}^{\mathbf{2}}$ \\
\hline UCS & 94.5 & 2.75 & 0.94 \\
BTS & 63.5 & 3 & 0.64 \\
\hline
\end{tabular}

RMSE root mean square error, VAF\% value account for and $\mathrm{R}^{2}$

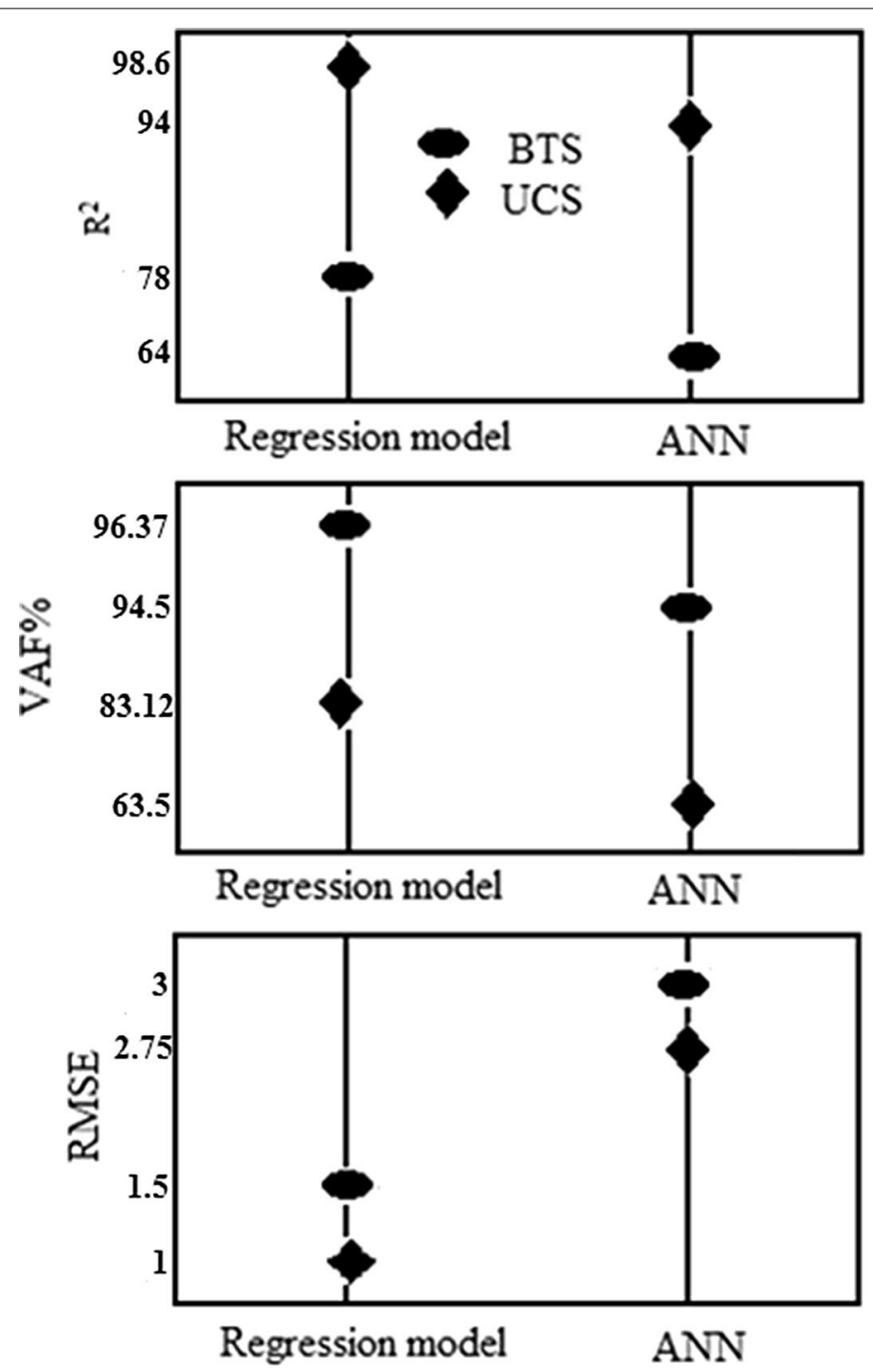

Fig. 7 Comparison of the values of RMSE, VAF, $R^{2}$ for Regression model, ANN models

The comparison of VAF, RMSE indices and coefficient of correlations $\left(R^{2}\right)$ for predicting UCS and BTS can be seen in Fig. 7.

\section{Conclusion}

The main conclusions arising from the current study, is that the UCS and BTS were found to be correlated with $\mathrm{I}_{\mathrm{s}(50)}$ through nonlinear relationships. The result obtains from UCS shows higher correlation than BTS for both regression and ANN methods. 
This study may be checked further for validation, it is strongly suggested other studies extended to petrography and physical properties of Conglomerates.

\section{Authors' contributions}

The idea of present article was conceived by BM. BM performed analytical methods and computation. KA provide data base, supervised all theory development and analytical methods. Both authors discussed the results and contributed to the final manuscript. Both authors read and approved the final manuscript.

\section{Author details}

${ }_{1}^{1}$ Department of Engineering geology, Science and Research Branch, Islamic Azad University, Tehran, Iran. ${ }^{2}$ Department of Mining Engineering, Science and Research Branch, Islamic Azad University/University Square, End of North Sattari Highway, Po Box 14515/775 \& 14155/4933, Postal Code: 1477893855 Tehran, Iran.

\section{Competing interests}

The authors declare that they have no competing interests.

Ethics approval and consent to participate

Not applicable.

Funding

This research did not receive any specific grant from any funding agencies in the public, commercial, or not-for-profit sectors.

\section{Publisher's Note}

Springer Nature remains neutral with regard to jurisdictional claims in published maps and institutional affiliations.

Received: 30 March 2016 Accepted: 3 September 2017

Published online: 12 September 2017

\section{References}

1. D'Anrea DV, Fisher RL, Fogelson DE (1964) Prediction of compression strength from other rock properties. Colo Sch Mines Q 59(4B):623-640

2. Reichmuth DR (1968) Point load testing of brittle materials to determined tensile strength and relative brittleness. Proceedings of the 9th US Symposium on Rock mechanical University of Colorado

3. Broch EM, Franklin JA (1972) The point load strength test. Int J Rock Mech Min Sci 9(6):669-697

4. Bieniawski ZT (1975) The point load test in geotechnical practice. Eng Geol 9:1-11

5. ISRM suggested methods (1985) Suggested method for determining point-load strength. Int J Rock Mech Min Sci Abstr. 22:53-60

6. Oztruk $\mathrm{H}$, Altinpinar M (2017) The estimation of uniaxial compressive strength conversion factor of trona and interbeds from point load tests and numerical modeling. J Afr Earth Sci 131:71-79

7. Ferentinou M, Fakir M (2017) An ANN approach for the prediction of uniaxial compressive strength, of some sedimentary and igneous rocks in eastern KwaZulu-Natal. Procedia Eng 191:1117-1125

8. Basu A, Mishra DA, Roychowdhury K (2013) Rock failure modes under uniaxial compression, Brazilian, and point load tests. Bull Eng Geol Environ 72:457-475

9. Akram M, Bakar MA (2016) Correlation between uniaxial compressive strength and point load index for salt-range rocks. Pak J Eng Sci. 1:1-8

10. Quane SL, Russel JK (2003) Rock strength as a metric of welding intensity in pyroclastic deposits. Euro J Mineral 15:855-864

11. Kahraman S (2014) The determination of uniaxial compressive strength from point load strength for pyroclastic rock. Eng Geol 170:33-42

12. Fener M, Kahraman S, Bilgil A, Gunaydin O (2005) Evaluation of indirect methods to estimate the compressive strength. Rock Mech Rock Eng 38(4):329-343

13. Basu A, Aydin A (2006) Predicting uniaxial compressive strength by point load test; significance of cone penetration. Rock Mech Rock Eng 39(5):483-490. doi:10.1007/s00603-006-0082-y

14. Agustawijaya DS (2007) The uniaxial compressive strength of soft rock. Civ Eng Dimens 9(1):9-14

15. Cobanglu I, Celik SB (2008) Estimation of uniaxial compressive strength from point load strength, Schmidt hardness and P-wave velocity. Bull Eng Geol Environ 67:491-498. doi:10.1007/s10064-008-0158-x

16. Sabatakakis N, Koukis G, Tsiambaos G, Papanakli S (2009) Index properties and strength variation controlled by microstructure for sedimentary rocks. Eng Geol 97:80-90

17. Kahraman S, Gunaydin O (2009) The effect of rock classes on the relation between uniaxial compressive strength and point load index. Bull Eng Geol Environ 69:345-353. doi:10.1007/s10064-009-0195-0

18. Grasso P, Xu S, Mahtab A (1992) Problem and promises of index testing of rocks. Proceeding of the 33rd US symposium on rock mechanics

19. Tsiambaos G, Sabatakakis N (2004) Considerations on strength of intact sedimentary rocks. Eng Geol 72:261-273. doi:10.1016/j.enggeo.2003.10.001

20. ISRM (1981) Rock characterization, testing and monitoring. ISRM suggested methods, Pergamon, p 211

21. Yilmaz I, Yuksek AG (2007) An example of artificial neural network application for indirect estimation of rock parameters. Rock Mech Rock Eng 5(41):781-795 
22. Singh TN, Kanchan R, Verma AK, Singh S (2003) An intelligent approach for prediction of triaxial properties using unconfined uniaxial strength. Min Eng J 5:261-273

23. Simpson PK (1990) Artificial neural system-foundation, paradigm, application and implementation. Pergamon, New York

24. Zorlu K, Gokceoglu C, Ocakoglu F, Nefslioglu HA, Acikalin S (2008) Prediction of compressive strength of sandstones using petrogheraphy-based models. Eng Geol 96:141-156

25. Vallejo LE, Welsh RA, Robinson MK (1989) Correlation between unconfined compressive and point load strength for Appalachian rocks. In: Proceeding of 30th US symposium on rock mechanics, Morgantown, pp 461-468

26. Chau KT, Wong RHC (1996) Uniaxial compressive strength and point load strength of rocks. Int J Rock Mech Min Sci Geomech Abstr 33(2):183-188

27. Smith HJ (1997) The point load test for weak rock in dredging applications. Int J Rock Mech Min Sci 34(3-4):295. e1-295.e13

28. Palchik V, Hatzor YH (2002) Crack damage stress as a composite function of porosity and elastic matrix stiffness in dolomites and limestones. Eng Geol 63(3-4):233-245

\section{Submit your manuscript to a SpringerOpen ${ }^{\circ}$} journal and benefit from:

- Convenient online submission

- Rigorous peer review

- Open access: articles freely available online

- High visibility within the field

Retaining the copyright to your article

Submit your next manuscript at $\boldsymbol{\Delta}$ springeropen.com 